\title{
Epinephrine auto-injector needle length
}

The impact of winter clothing

Sten Dreborg ${ }^{1 *}$ (D) Gina Tsai ${ }^{2}$ (ID and Harold Kim $^{2,3}$ (D)

\begin{abstract}
Background: Epinephrine auto-injectors are expected to deliver the drug intramuscularly.

Objective: To study whether injection through clothing influences the frequency of subcutaneous and intraosseous/ periosteal deposition of epinephrine.

Methods: Skin to muscle and skin to bone distances were measured for 303 children and adolescents and 99 adults. Distance was determined by ultrasound, with high or low pressure on the ultrasound probe. The risk/percentage of subcutaneous and intraosseous/periosteal injections was calculated using the lower and upper limits for the authority-approved length of EAI needles as provided by two high pressure EAI manufacturers and one low pressure EAI manufacturer. The addition winter clothing on the delivery of epinephrine was illustrated by comparing drug delivery fissue depth with no clothes. Furthermore, the riof non-intramuscular delivery for the shortest and longest approved needle length was calculated.

Results: When using Epipen $\mathrm{Jr} \mathrm{r}^{\circledR}$ in children $<15 \mathrm{~kg}$ the risk of intraosseous/periostal injection was reduced from $1 \%$ and 59\% for the shortest and longest approved needle length to 0 and $15 \%$ with winter clothes. The Auvi-Q ${ }^{\circledR} 0.1 \mathrm{mg}$ had no risk of intraosseous/periosteal injection. However, the subcutaneous deposition risk increased from $94 \%$ and $28 \%$ to $100 \%$ and $99 \%$ with winter clothes. The risk of subcutaneous injection using Epipen $\mathrm{rr}^{\circledR}$ in the youngest children increased from $13 \%$ and $0 \%$ to $81 \%$ and $1 \%$ with winter clothes, and with Epipen ${ }^{\circledR}$ in adults from $45 \%$ and $17 \%$ to $60 \%$ and $38 \%$. Emerade ${ }^{\circledR}$, had a risk of subcutaneous injection in adults increasing from $14 \%$ and $10 \%$ to $28 \%$ and $21 \%$ adding winter clothes.
\end{abstract}

Conclusion: The risk of intraosseous/periosteal injections decreases and the risk of subcutaneous injection increases when injecting through winter clothes for all EAls.

Keywords: Auto-injector, Epinephrine, Intramuscular, Subcutaneous, Intraosseous, Periosteal, Skin to bone distance, Skin to muscle distance, Clothing

\section{Background}

Epinephrine is indicated for intramuscular injection in the treatment of anaphylaxis [1]. We recently reported on the risk for subcutaneous and intraosseous/periosteal injections, using ultrasound for measuring the distance from skin to muscle and bone, respectively [2-6]. There

*Correspondence: sten.dreborg@kbh.uu.se

${ }^{1}$ Department Child and Adolescent Allergology, Women's and Children's Health, University of Uppsala, Uppsala, Sweden

Full list of author information is available at the end of the article was a risk of subcutaneous injection when using both high pressure EAIs (HPEAIs) with $94 \%$ risk in small children using Auvi- ${ }^{\circledR} 0.1 \mathrm{mg}$ and in about $28 \%$ in adult overweight women using Epipen ${ }^{\circledR}$ [2]. In addition, there was a $71 \%$ risk risk of an intraosseous/periosteal injection in small children when using Auvi-Q $\mathrm{Q}^{\circledR} 0.15$ mg HPEAIs [5].

There are two important factors influencing the risk of intraosseous/periosteal injection and subcutaneous injection. The pressure applied and the length of the needle penetrating the skin.

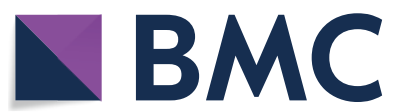

(c) The Author(s) 2020. This article is licensed under a Creative Commons Attribution 4.0 International License, which permits use, sharing, adaptation, distribution and reproduction in any medium or format, as long as you give appropriate credit to the original author(s) and the source, provide a link to the Creative Commons licence, and indicate if changes were made. The images or other third party material in this article are included in the article's Creative Commons licence, unless indicated otherwise in a credit line to the material. If material is not included in the article's Creative Commons licence and your intended use is not permitted by statutory regulation or exceeds the permitted use, you will need to obtain permission directly from the copyright holder. To view a copy of this licence, visit http://creativeco mmons.org/licenses/by/4.0/. The Creative Commons Public Domain Dedication waiver (http://creativecommons.org/publicdomain/ zero/1.0/) applies to the data made available in this article, unless otherwise stated in a credit line to the data. 
We applied low pressure on the ultrasound probe to mimic the pressure applied on low pressure EAIs (LPEAIs) and higher pressure (about $8 \mathrm{lb}$ or 35 Newtons $(\mathrm{N}))$ on the probe to mimic the pressure applied to HPEAIs [2-4].

Our data were based on ultrasound estimation of the naked skin to muscle distance and the naked skin to bone distance, respectively. In clinical practice, allergists typically suggest that these devices can and should be delivered through clothing. In colder climates, people often wear thicker clothing during the winter months. There is no published data on the possible influence of thick clothing on skin to muscle distance and skin to bone distance using HPEAIs or LPEAIs. This information may be clinically helpful in predicting expected intramuscular delivery of epinephrine.

The aim of this communication is to study the influence of winter clothing on the risk for intraosseous/periosteal and subcutaneous injection with currently available EAIs, taking in account the variation in needle length within batches of EAIs released for marketing.

\section{Methods}

Four hundred and one (401) consecutive patients with diagnosed food allergy were included. As described earlier, 302 children and adolescents and 99 adults (67 women) underwent ultrasound investigations using high $(8 \mathrm{lb}=35 \mathrm{~N})$ and minimal pressure on the probe, noting the skin to bone distance and skin to muscle distance on the mid third of the anterio-lateral aspect of the right thigh [2-4]. Clinical data and basic statistical analyses have been published [2-4]. Moreover, the possible risk of having a subcutaneous instead of an intramuscular injection and the possible risk of having an intraosseous/ periosteal injection was analysed in two previous papers $[5,6]$. The main findings were an increased risk of subcutaneous injection in adolescents and especially overweight adult women [2, 5]. Furthermore, EAI needles of the same brand vary in length. The shortest allowable needles increase the risk of subcutaneous injection, the longest the risk of intraosseous/periosteal injection [6].

There were two groups of children less than 12 years of age: $0-15 \mathrm{~kg}(\mathrm{n}=100)$ [3], $15-30 \mathrm{~kg}(\mathrm{n}=102)$ and one group of adolescents $>12$ years of age and weighing more than $30 \mathrm{~kg}(\mathrm{n}=100)$ [4], totalling 302 (125 girls and 177 boys). Furthermore, 99 adults (18-72 yrs, 67 females), were included in the study [2]. Patients, parents or legal guardians provided written, informed consent before participating in the original studies [2-4].

The needle full length when the EAI is applied on naked skin, and through thick winter cloth was studied. To illustrate the risks, we used the maximum length and the minimum length passing internal controls, Table 1 , as earlier described [6].

Recently, Diacono et al. [7] found the whole needle orifice must pass completely into the muscle for proper administration of an intramuscular injection. The skin to muscle distance is measured from the skin surface to the outer side of the fascia. The needle must pass through the fascia and the epimysium into the muscle. If part of the orifice of the needle is within the epimysium during the injection, epinephrine may spread within the loose epimysium tissue. The length of the needle's eye of the EAIs was estimated to be $2 \mathrm{~mm}$ [5]. Therefore, the needle length was reduced by $2 \mathrm{~mm}$ when estimating the risk for subcutaneous injection. The thickness of pants worn by children, adolescents and adults varies much. We measured the thickness of 3 winter pants. And with compression, the thickest of them was about three millimeters. The three $\mathrm{mm}$ is just an example, it illustrates that the thickness of clothing influences the outcome of injection with EAIs. Therefore, the needle lengths were reduced by $3 \mathrm{~mm}$ when estimating the risks for intraosseous/periosteal or subcutaneous injection when wearing thick winter clothes. In case of much thicker or thinner clothes, approximate risks can be calculated from the figures. The needle lengths used for calculation of the risk of intraosseous/periosteal and subcutaneous injection are given in Table 1.

\section{Outcome variables}

We used two primary outcome variables: the proportion of children with (1) skin to bone distance less than the total needle length and that length minus $3 \mathrm{~mm}$ (thick clothing) and (2) skin to muscle distance more than the needle length minus $2 \mathrm{~mm}$, and the needle length minus $5 \mathrm{~mm}$ (Table 1). Furthermore, the key evaluation parameter is the change of the risk of subcutaneous and intraosseous/periosteal injection when injecting through thick winter clothes. In the results section, we give the percent at risk using the shortest needle\%-the longest needle\%.

\section{Statistics}

Basic statistical significances and correlations have been reported previously [5-7].

We estimated the proportion of subjects who would likely receive epinephrine intraosseous/periosteal or subcutaneous, respectively, using high and low pressure EAIs.

Since differences in distance are small and therefore data approximate, we have proposed the use of risk classes rather than exact data [6]. The color codes indicating classes of risk are: 
Table 1 Auto-injector needles available in North America and Europe in 2019

\begin{tabular}{|c|c|c|c|c|c|c|}
\hline \multirow[t]{2}{*}{ EAI } & \multirow{2}{*}{$\begin{array}{l}\text { Lower and upper } \\
\text { limits for needle } \\
\text { length }\end{array}$} & \multicolumn{2}{|l|}{ Naked skin } & \multicolumn{2}{|c|}{ With thick clothes $3 \mathrm{~mm}$} & \multirow{2}{*}{$\begin{array}{l}\text { Pressure } \\
\text { against the thigh }\end{array}$} \\
\hline & & $\begin{array}{l}\text { Skin to muscle } \\
\text { distance }-2 \mathrm{~mm} \\
\text { (acc. to Diacono) }\end{array}$ & $\begin{array}{l}\text { Skin to bone } \\
\text { distance full } \\
\text { length }\end{array}$ & $\begin{array}{l}\text { Skin to muscle } \\
\text { distance } \\
(-3 \mathrm{~mm} \text { clothes } \\
\text { and }-2 \mathrm{~mm})=- \\
5 \mathrm{~mm}\end{array}$ & $\begin{array}{l}\text { Skin to bone } \\
\text { distance full pene- } \\
\text { trating needle } \\
\text { length }-3 \mathrm{~mm}\end{array}$ & \\
\hline \multicolumn{7}{|l|}{ HPEAl ${ }^{\mathrm{a}}$} \\
\hline \multirow[t]{2}{*}{ Epipen $\mathrm{Jr}^{\circledR} 0.15 \mathrm{mg}$} & Lower limit & 8 & 10 & 5 & 7 & \multirow[t]{4}{*}{ Press hard } \\
\hline & Upper limit & 13 & 15 & 10 & 12 & \\
\hline \multirow[t]{2}{*}{ Epipen ${ }^{\circledR} 0.3$ mg } & Lower limit & 11 & 13 & 8 & 10 & \\
\hline & Upper limit & 16 & 18 & 13 & 15 & \\
\hline \multirow[t]{2}{*}{ Auvi-Q $0.1 \mathrm{~mm}$} & Lower limit & 4.4 & 6.4 & 1.4 & 3.4 & \multirow[t]{6}{*}{ Push firmly } \\
\hline & Upper limit & 6.9 & 8.9 & 3.9 & 5.9 & \\
\hline \multirow[t]{2}{*}{ Auvi-Q $0.15 \mathrm{mg}$} & Lower limit & 9.4 & 11.4 & 6.4 & 8.4 & \\
\hline & Upper limit & 12 & 14.0 & 9 & 11 & \\
\hline \multirow[t]{2}{*}{ Auvi-Q 0.3 mg } & Lower limit & 12.7 & 14.7 & 9.7 & 11.7 & \\
\hline & Upper limit & 15.3 & 17.3 & 12.3 & 14.3 & \\
\hline \multicolumn{7}{|l|}{ LPEAI $^{\mathrm{b}}$} \\
\hline \multirow[t]{2}{*}{ Emerade $^{\circledR} 0.15 \mathrm{mg}$} & Lower limit & 13 & 15 & 10.0 & 12.0 & \multirow[t]{6}{*}{ Slight pressure } \\
\hline & Upper limit & 14.7 & 16.7 & 11.7 & 13.7 & \\
\hline Emerade ${ }^{\circledR} 0.3 \mathrm{mg}$ & Lower limit & 20.1 & 22.1 & 17.1 & 19.1 & \\
\hline Slight preesure & Upper limit & 21.6 & 23.6 & 18.6 & 20.6 & \\
\hline \multirow[t]{2}{*}{ Emerade $^{\circledR} 0.5 \mathrm{mg}$} & Lower limit & 20.1 & 22.1 & 17.1 & 19.1 & \\
\hline & Upper limit & 21.6 & 23.6 & 18.6 & 20.6 & \\
\hline
\end{tabular}

Needle lengths are given according to the manufacturers' approved specifications. The skin to muscle distance is based on Diacono et al. [7] by subtracting $2 \mathrm{~mm}$ from the penetrating needle length. The increased distance to muscle, i.e. $2 \mathrm{~mm}$ for the eye of the needle. The skin to bone distance is based on the full length of the needle. Both skin to muscle distance and skin to bone distance are given for the case injection is performed on naked skin and with winter cloths. The thickness of winter clothes is proposed to be $3 \mathrm{~mm}$, but can vary among individuals

a HPEAI, These devices are high-pressure epinephrine autoinjectors, HPEAls

${ }^{b}$ This device is a low-pressure epinephrine autoinjector, LPEAI

- white color, indicates very low risk, $0-2 \%$,

- green color, indicates low risk, $3 \%-9 \%$,

- orange color indicates medium risk, $10 \%-19 \%$ and

- red color indicates high risk, i.e. higher risk than $20 \%$, for intraosseous/periosteal injection. See also outcome parameters and Table 2.

\section{Results}

\section{Patient sample}

The basic results of the samples investigated have been published separately elsewhere [5-7]. In this study, we tested whether wearing thick clothes would effect the deposition of epinephrine, and taking also in account the variation in needle length, i.e. if using the shortest and the longest needle passing the quality control of the currently available EAIs, would affect the risk of subcutaneous injections or intraosseous/periosteal injections.

We tested one thickness of clothes, i.e. $3 \mathrm{~mm}$, compared to naked skin.

Since the EAI brands had different limits for acceptance of minimum and maximum length of the needle, the impact of variation in length has been analysed for each brand of EAI, Table 1.

\section{Skin to bone distance}

The risk for intraosseous/periosteal injection was highest, $1 \%$ and $59 \%$, using Epipen $\mathrm{rr}^{\circledR}$ in children weighing less than $15 \mathrm{~kg}$, decreasing to 0 and $15 \%$ when injected trough thick clothing and that of Epipen $\mathrm{rr}^{\circledR} 0.15 \mathrm{mg}$ in children weighing $15-30 \mathrm{~kg}$ from 1 and $30 \%$ to 0 and $6 \%$, Table 2 , Figs. 1 and 2.

Using the newly lauched Auvi- $\mathrm{Q}^{\circledR} 0.1 \mathrm{mg}$ EAI, designed to avoid intraosseous/periosteal injection, showed no risk $(0 \%)$ of intraosseous/periosteal injection in children less than $15 \mathrm{~kg}$. In children $15-30 \mathrm{~kg}$, the Auvi-Q ${ }^{\circledR}$ $0.15 \mathrm{mg}$ had a $22 \%$ and $3 \%$ risk of intraosseous/periosteal injection, Table 2, Fig. 2.

The LPEAI Emerade ${ }^{\circledR}$ had very low risk of intraosseous/ periosteal penetration in young children.

Winter clothing reduced the risk of intraosseous/ periosteal deposition in all age groups. 
Table 2 The skin to bone distance in relation to weight

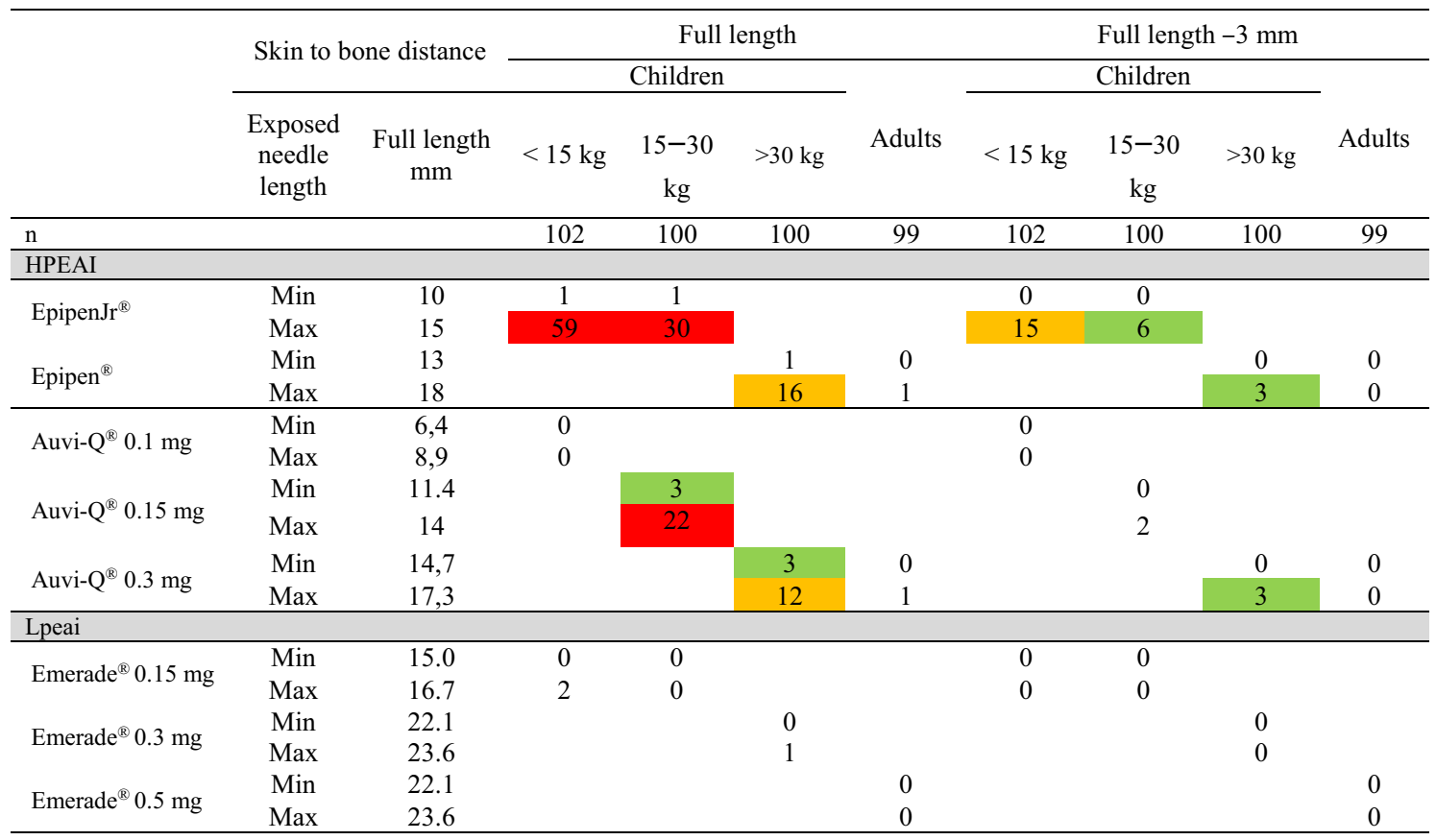

The full length and the full length minus $3 \mathrm{~mm}$, the proposed penetrating needle length wearing winter clothes, was used at calculation of skin to bone distance. The risk of intraosseous/periosteal injection was calculated for both the longest and the shortest needle passing quality control. The weight limits were $(<15 \mathrm{~kg}), 15-30 \mathrm{~kg}$, adolescents weighing $>30 \mathrm{~kg}$ and adults, Table 1

White color indicates very low risk, $0 \%-2 \%$, green color indicates low risk, 3\%-9\%, orange color indicates medium risk, 10\%-19\%, red color higher risk than $20 \%$, for intraosseous/periosteal injection. The exposed needle lengths are given in $\mathrm{mm}$

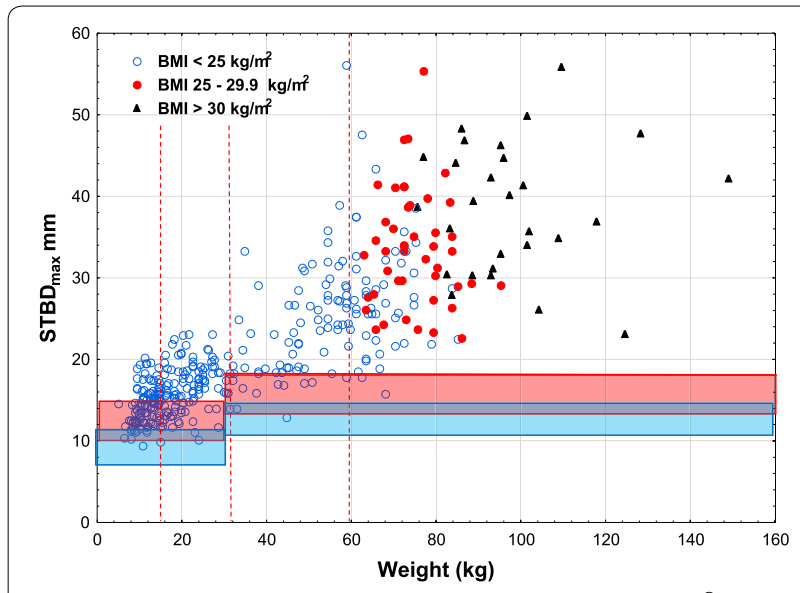

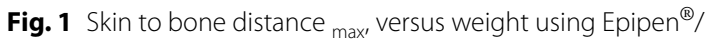
Epipen $\mathrm{r}^{\circledR}$ EAls. The full exposed length of the needles with upper and lower limits (red lines) with the variation indicated by the red area and the full length minus $3 \mathrm{~mm}$ for winter clothing shown below (blue lines and area). The vertical lines indicate the shift in dose from $0.15 \mathrm{mg}$ to $0.3 \mathrm{mg}$ and from $0.3 \mathrm{mg}$ to $0.5 \mathrm{mg}$, respectively. BMl limits for adults and symbols are indicated in the left upper corner

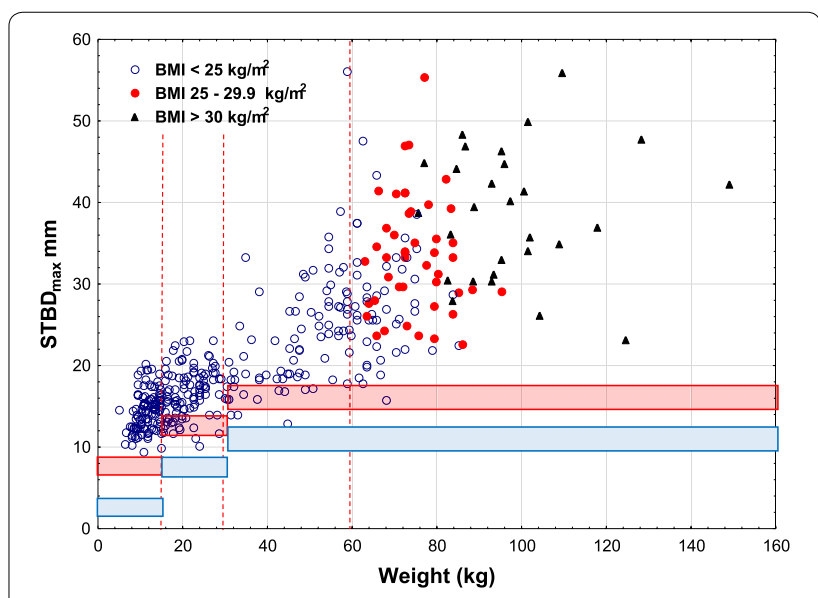

Fig. 2 Skin to bone distance max versus weight using Auvi-Q ${ }^{\circledR}$ EAls. The legend to Fig. 1 explains the lines 


\section{Skin to muscle distance}

Using the HPEAI Epipen ${ }^{\circledR} /$ Epipen $\mathrm{Jr}^{\circledR}$, the percentage of children less than $15 \mathrm{~kg}$ increased from $13 \%$ and $0 \%$ to $81 \%$ and $1 \%$ and in those weighing $15-30 \mathrm{~kg}$ rom $8 \%$ and $0 \%$ to $71 \%$ and $1 \%$, when using thick clothes. The gap depending on the difference in needle length allowed for batch release.

When using the new Auvi- $Q^{\circledR} 0.10$ mg EAI in small children on naked skin, there was a very high risk of subcutaneous injection, $94 \%$ and $28 \%$, that was increased when injecting trough winter clothes, to $100 \%$ and $-99 \%$, Table 3, Fig. 4.

Using Emerade ${ }^{\circledR}$, the risk of subcutaneous injection was intermediate, $14 \%$ and $10 \%$, in adults and increased to $28 \%$ and $21 \%$ when wearing winter clothes, Table 3 and Fig. 5.

Winter clothing increased the risk of subcutaneous injection in all age groups.

\section{Discussion}

In recent years the risk of subcutaneous or intraosseous injection of epinephrine using EAIs has been widely discussed. This paper is based on data from three original publications [2-4]. Those three studies represents the most extensive investigation of the relationships between the distances from skin to muscle, and skin surface to the bone. Distances were determined by ultrasound at the mid anterolateral aspect of the thigh, the recommended area for intramuscular injection of epinephrine using EAIs [8].
The influence of thick clothing on the deposition of epinephrine has not been investigated previously. In this paper, we analysed the influence of thick clothing on skin to muscle distance and skin to bone distance vs. weight, the most commonly used parameter for dosing epinephrine. All winter clothing does not have the same thickness. We decided to use $3 \mathrm{~mm}$ and to estimate compressed winter clothing thickness based on caliper measurements. The result of thicker or less thick winter clothing can easily be calculated from the figures in this paper.

The true distance from skin to muscle and bone during the delivery of epinephrine with an EAI will vary with the pressure applied to release the needle of the EAI [2-6]. In previous studies, we identified that EAIs that require high pressure likely compress primarily muscle tissue, which reduces the distance from skin surface to the bone. We estimate that about $90 \%$ of the compression originates from compression of the muscle and not from compression of the subcutaneous tissue [2-4].

In a previous paper, we used the limits for acceptance of needle lengths from the manufacturers' internal specifications, kindly supplied by the manufacturers [6]. This data was also used in this communication. The risk of intraosseous/periosteal penetration was most pronounced using EpipenJ $\mathrm{r}^{\circledR}$ in small children. The likelihood of subcutaneous injection was highest with the newly introduced Auvi- ${ }^{\circledR} 0.1 \mathrm{mg}$ epinephrine EAI and in adult obese women [2]. Our findings suggest that it is difficult to obtain reduced

Table 3 The skin to muscle distance in relation to weigh

\begin{tabular}{|c|c|c|c|c|c|c|c|c|c|c|c|c|}
\hline & & \multirow{2}{*}{\multicolumn{3}{|c|}{ Skin to muscle distance }} & \multirow{2}{*}{\multicolumn{4}{|c|}{$\begin{array}{l}\text { Full length }-2 \mathrm{~mm} \\
\text { Children }\end{array}$}} & \multicolumn{4}{|c|}{ Full length $-5 \mathrm{~mm}$} \\
\hline & & & & & & & & & \multicolumn{3}{|c|}{ Children } & \multirow[b]{2}{*}{ Adults } \\
\hline & & $\begin{array}{c}\text { Exposed } \\
\text { needle } \\
\text { length }\end{array}$ & $\begin{array}{c}\text { Full } \\
\text { length } \\
-2 \\
\mathrm{~mm} \\
\end{array}$ & $\begin{array}{c}\text { Full } \\
\text { length } \\
-5 \\
\mathrm{~mm} \\
\end{array}$ & $\begin{array}{c}<15 \\
\mathrm{~kg}\end{array}$ & $\begin{array}{c}15-30 \\
\mathrm{~kg}\end{array}$ & $>30 \mathrm{~kg}$ & Adults & $\begin{array}{c}<15 \\
\mathrm{~kg}\end{array}$ & $15-30 \mathrm{~kg}$ & $>30 \mathrm{~kg}$ & \\
\hline $\mathrm{n}$ & & & & & 102 & 100 & 100 & 99 & 102 & 100 & 100 & 99 \\
\hline \multicolumn{13}{|l|}{ HPEAI } \\
\hline \multirow{2}{*}{ EpipenJr $^{\circledR}$} & Min & 10 & 8 & 5 & 13 & 8 & & & 81 & 71 & & \\
\hline & Max & 15 & 13 & 10 & 0 & 0 & & & 1 & 1 & & \\
\hline \multirow{2}{*}{ Epipen $^{\circledR}$} & Min & 13 & 11 & 8 & & & 11 & 45 & & & 32 & 60 \\
\hline & Max & 18 & 16 & 13 & & & 1 & 17 & & & 6 & 38 \\
\hline \multirow{2}{*}{ Auvi- $Q^{\circledR} 0.1 \mathrm{mg}$} & Min & 6.4 & 4,4 & 1,4 & 94 & & & & 100 & & & \\
\hline & Max & 8.9 & 6,9 & 3.9 & 28 & & & & 99 & & & \\
\hline \multirow{2}{*}{ Auvi-Q ${ }^{\circledR} 0.15 \mathrm{mg}$} & Min & 11.4 & 9.4 & 6.4 & & 3 & & & & 24 & & \\
\hline & Max & 14 & 12 & 9 & & 0 & & & & 5 & & \\
\hline \multirow{2}{*}{ Auvi-Q ${ }^{\circledR} 0.3 \mathrm{mg}$} & Min & 14.7 & 12,7 & 9.7 & & & 7 & 38 & & & 18 & 52 \\
\hline & Max & 17.3 & 15,3 & 12.3 & & & 1 & 22 & & & 7 & 40 \\
\hline \multicolumn{13}{|l|}{ LPEAI } \\
\hline \multirow{2}{*}{ Emerade $^{\circledR} 0.15 \mathrm{mg}$} & Min & 15 & 13.0 & 10 & 1 & 0 & & & 7 & 4 & & \\
\hline & Max & 16.7 & 14.7 & 11.7 & 0 & 0 & & & 3 & 1 & & \\
\hline \multirow{2}{*}{ Emerade $^{\circledR} 0.3 \mathrm{mg}$} & Min & 22.1 & 20.1 & 17.1 & & & 0 & & & & 4 & \\
\hline & Max & 23.6 & 21.6 & 18.6 & & & 0 & & & & 1 & \\
\hline \multirow{2}{*}{ Emerade $^{\circledR} 0.5 \mathrm{mg}$} & Min & 22.1 & 20.1 & 17.1 & & & & 14 & & & & 28 \\
\hline & Max & 23.6 & 21.6 & 18.6 & & & & 10 & & & & 21 \\
\hline
\end{tabular}

Weight limits and color coding as in Table 2. The full length minus $2 \mathrm{~mm}$, due to the finding by Diacono et al. [7] that the full needle eye must pass the endomysium into the muscle and the full length minus $5 \mathrm{~mm}$, i.e. $2 \mathrm{~mm}$ according to Diacono [7] and the proposed thickness of winter clothes, $3 \mathrm{~mm}$, was used at calculation of skin to muscle distance. The risk of subcutaneous injection was calculated for both the longest and the shortest needle passing quality control 
risk of both intraosseous/periosteal injection and subcutaneous injection using the same HPEAI. A rough estimate would be to calculate the minimum value of intraosseous/periosteal. Injection combined with the minimum number subcutaneous injection.

In this study, we found the highest risk for intraosseous/periosteal injection at 59 and $1 \%$ in children weighing less than $15 \mathrm{~kg}$ when using the longest needle of Epipen $\mathrm{Jr}^{\circledR}$ that is accepted by the manufacturer. Thick clothing reduced the risk to 15 and $0 \%$.

According to our data, the Auvi- $\mathrm{Q}^{\circledR} 0.1 \mathrm{mg}$ has an estimated risk of bone injection in children less than $15 \mathrm{~kg}$ of $0 \%$. However, this EAI has a marked increase in subcutaneous injection from 28 and $94 \%$ for naked skin to 100 and $99 \%$ if injected through winter clothing, Table 3. This illustrates the difficulty to design an EAI that has both a low risk of intraosseous/periosteal injection and subcutaneous injection.

In adults, winter clothing reduced the risk of intraosseous/periosteal injection from 16 and 3\% using the longest needles of Epipen ${ }^{\circledR}$ and from 12 and 3\% using Auvi- $\mathrm{Q}^{\circledR}$. Emerade ${ }^{\circledR}$ had no risk of intraosseous/ periosteal injection in adults.

On the other hand, using the shortest approved needles in adults, the risk of subcutaneous injection increased for Epipen ${ }^{\circledR}$ from $45 \%$ to $60 \%$, for Auvi-Q ${ }^{\circledR}$ from 38 to $52 \%$ and for Emerade from 14 to $28 \%$.

It would be desirable to have a longer needle length available in EAIs for the obese and overweight adults having the risk of subcutaneous injection. The risk for these patients must be better defined than by weight.

It may be possible to better characterize patients to identify those at risk for subcutaneous injection by Auvi- $Q^{\circledR} 0.1 \mathrm{mg}$, intraosseous/periosteal injection using Epipen $\mathrm{r}^{\circledR}$ and Auvi-Q $0.15 \mathrm{mg}$, and adults at risk of subcutaneous injection.

In general, winter clothing reduced the risk of intraosseous/periosteal injection in children and increased the risk of subcutaneous injection in adults and in children using Auvi- $Q^{\circledR} 0.1 \mathrm{mg}$ epinephrine EAIs.

In this series of studies [2-4], we used $8 \mathrm{lb}$ or about 35 Newtons $(\mathrm{N})$ as high pressure and applied a low pressure to mimic the required pressure to release the needle of HPEAIs and LPEAIs, respectively. The declared variation in pressure that is accepted by companies for release of new batches, applied to EAIs has been presented elsewhere [9]. There are instruments that can apply a specified pressure to the ultrasound probe and such instruments should be used in all future trials and in the instruction to prescribing health care personnel $[10,11]$. Furthermore, we propose the variation in needle length and the influence of thick clothes should be defined.
In future trials, we recommend the pressure applied to the ultrasound probe should be applied at the lowest and the highest pressure levels according to the specifications for each device.

Furthermore, the probe should have the same foot print as that of the specific EAI. This applies to both the EAIs available on the market at present as well as new brands or modifications of the presently available brands.

In our opinion, it is difficult to find a needle a length that would have no risk of intraosseous/periosteal injection and at the same time no risk of subcutaneous injection employing the present approach with the high pressure injection technique. Performing ultrasounds on individual patients could better estimate the risks in individual patients.

In the figures, we indicated BMI limits for adults. In adults, it seems that BMI does not add to the selection of obese patients for estimation of the risk of subcutaneous injection Figs. 3, 4 and 5.

Recently, Duong et al. presented data on BMI versus skin to muscle distance and skin to bone distance without considering the age dependant successive increase of BMI [12]. BMI-limits in childhood and adolescence must include evaluation using age dependent and puberty stage dependant limits for BMI using z-scores. This is a complex task and will be investigated in the future.

Based on our ultrasound estimations of the skin to bone distance and skin to muscle distance, some EAIs, currently available in Europe and North America, do not likely deliver epinephrine intramuscularly in a significant number of patients. When wearing thick clothes, the risk of subcutaneous injection in overweight and especially obese patients is increased, and the risk of intraosseous/periosteal injection in

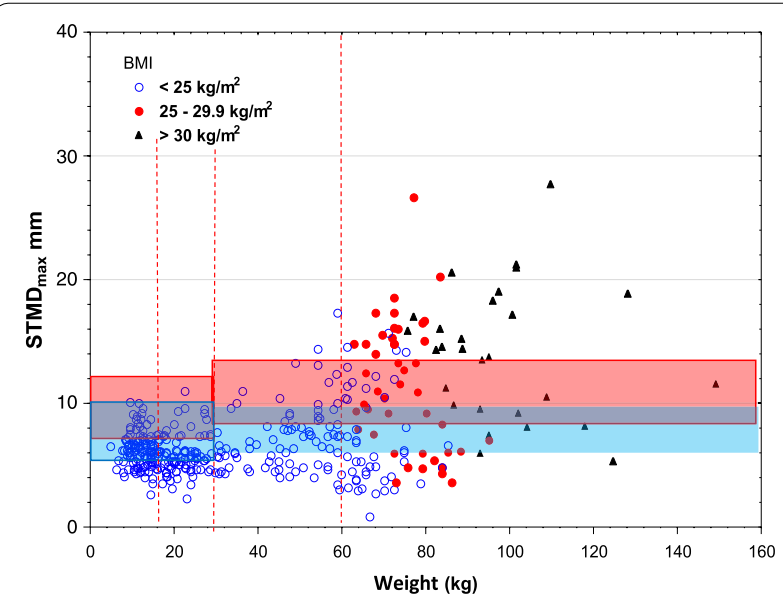

Fig. 3 Skin to muscle distance, max, versus weight using Epipen ${ }^{\circledR} /$ Epipen $J r^{\circledR}$ EAls. The legend to Fig. 1 explains the lines 


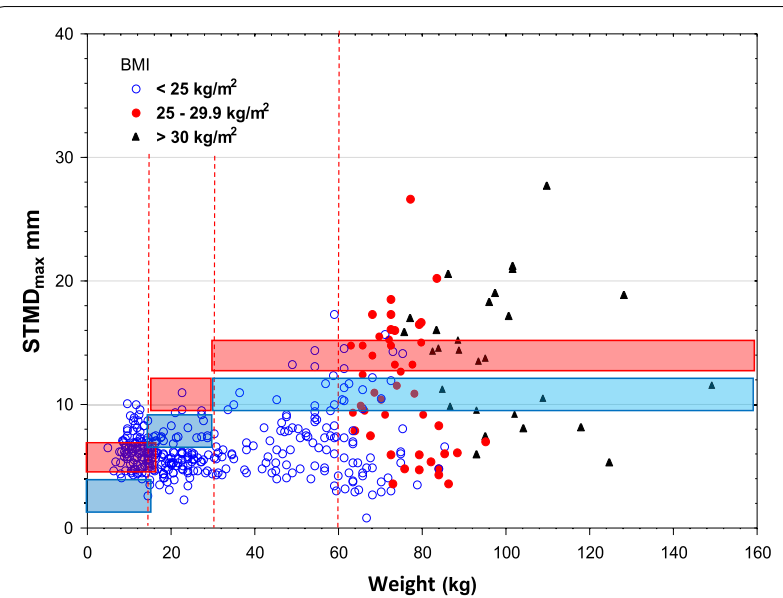

Fig. 4 Skin to muscle distance max versus weight using Auvi-Q ${ }^{\circledR}$ EAls. The legend to Fig. 1 explains the lines

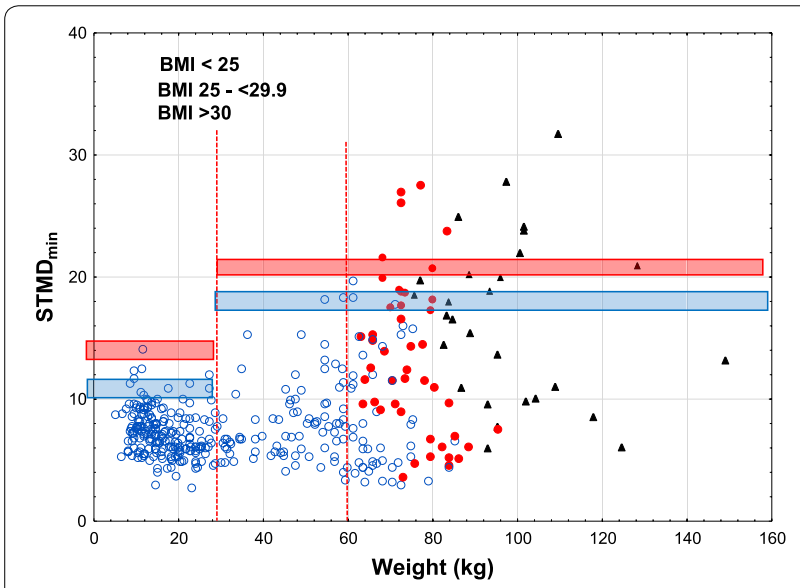

Fig. 5 Skin to muscle distance ${ }_{\text {min }}$ versus weight using Emerade ${ }^{\circledR}$ EAls. The legend to Fig. 1 explains the lines

young children using HPEAIs is reduced. In children weighing less than $15 \mathrm{~kg}$ the new Auvi- $\mathrm{Q}^{\circledR} 0.1 \mathrm{mg}$ EAI has no risk of intraosseous/periosteal injection but it has a $100 \%$ risk of subcutaneous injection wen injected through thick clothing. The only LPEAI, Emerade ${ }^{\circledR}$, has a low risk of intraosseous injection, but a risk of subcutaneous injection in adult overweight/obese patients.

When developing and evaluating new EAIs and updating existing EAIs, it will be a challenge to balance the risk of subcutaneous injection and intraosseous/ periosteal injection when considering the influence of thick winter clothing. There are some points that must be considered:
1. The variation of the length of the part of the needle exposed, i.e. the part of needle inserted in the thigh. The variation depends on the narrow or wide range of needle lengths approved in batches released for marketing. Every EAI of each brand can have a needle that is as long as the longest allowed by the batch release limits. The variation can be supervised and the range can be decreased by improved manufacturing processes. The needle length should be modified according to the pressures needed for needle release and injection.

2. The variation in pressure between EAIs of a specific brand allowed for batch release of that brand. We asked the manufacturers for this information who generously supplied this data [13]. No-one has investigated the influence of variation of pressure on the EAIs.

3. A third parameter is the variation of clothing. We now have shown the potential influences that clothing has on the delivery of epinephrine.

4. Children and adolescents grow and humans of all ages vary in weight and configuration. Therefore the risk of subcutaneous and intraosseous/periosteal injection will also vary individually from time to time. The only proper solution is to perform ultra-sound determination of skin to bone distance and skin to muscle distance every time an EAI is prescribed.

5. The choice between increased risk for subcutaneous and intraosseous/periosteal injection, between the Scylla of intraosseous/periosteal injection or the Carybdis of subcutaneous injection, is depending on the other factors.

We believe that all of these papramerters must be taken into consideration in future studies.

\section{Conclusion}

When injecting EAIs through thick clothes, the risk of subcutaneous injection is increased in all subjects, especially in overweight and obese patients. The risk of intraosseous/periosteal injection in young children using HPEAIs is reduced.

\section{Abbreviations}

EAl: Epinephrine auto-injector; HPEAl: High pressure EAI; LPEAI: Low pressure EAl.

\section{Ackowledgements}

Not applicable. 


\section{Authors' contributions}

SD conceptualized this study, carried out the analyses, drafted the original manuscript, revised the manuscript. GT participated in designing the original studies, reviewed and revised the manuscript. HK conceptualized and designed the original studies and this study, reviewed and revised the manuscript. All authors read and approved the final manuscript.

\section{Funding}

Open access funding provided by Uppsala University.

\section{Availability of data and materials}

Basic data are available in Excel format. Furthermore, basic information is available in the three original reports, references $2-4$. The figures were produced by Statistical, using the Excel data.

\section{Ethics approval and consent to participate}

Not applicable to this paper.

\section{Consent for publication}

Not applicable.

\section{Competing interests}

Sten Dreborg and Gina Tsai have no conflict of interest. Harold Kim has been on the advisory boards for Kaleo and Pfizer.

\section{Author details}

${ }^{1}$ Department Child and Adolescent Allergology, Women's and Children's Health, University of Uppsala, Uppsala, Sweden. ${ }^{2}$ Department of Medicine, Western University, London, Canada. ${ }^{3}$ Department of Medicine, McMaster University, Hamilton, Canada.

Received: 31 August 2019 Accepted: 2 April 2020

Published online: 15 April 2020

\section{References}

1. Simons FE, Gu X, Simons KJ. Epinephrine absorption in adults: intramuscular versus subcutaneous injection. J Allergy Clin Immunol. 2001;108(5):871-3.

2. Tsai G, Kim L, Nevis IF, Dominic A, Potts R, Chiu J, et al. Auto-injector needle length may be inadequate to deliver epinephrine intramuscularly in women with confirmed food allergy. Allergy Asthma Clin Immunol. 2014;10(1):39.
3. Kim L, Nevis IF, Tsai G, Dominic A, Potts R, Chiu J, et al. Children under $15 \mathrm{~kg}$ with food allergy may be at risk of having epinephrine autoinjectors administered into bone. Allergy Asthma Clin Immunol. 2014;10(1):40.

4. Dreborg S, Wen X, Kim L, Tsai G, Nevis I, Potts R, et al. Do epinephrine auto-injectors have an unsuitable needle length in children and adolescents at risk for anaphylaxis from food allergy? Allergy Asthma Clin Immunol. 2016;12:11.

5. Dreborg S, Kim L, Tsai G, Kim H. Epinephrine auto-injector needle lengths: Can both subcutaneous and periosteal/intraosseous injection be avoided? Annals of allergy, asthma \& immunology: official publication of the American College of Allergy, Asthma, \& Immunology. 2018;120(6):648-53 e1.

6. Dreborg S, Kim H. Implications of variation of epinephrine auto-injector needle length Annals of allergy, asthma immunology: official publication of the American College of Allergy, Asthma Immunology. 2019: Accepted for publication.

7. Diacono D, Pumphrey RS, Sharma V, Arkwright PD. The deep fascia of the thigh forms an impenetrable barrier to fluid injected subcutaneously by autoinjectors. Journal Allergy Clin Immunol Pract. 2015;3(2):297-9.

8. Simons FE, Ardusso LR, Bilo MB, Cardona V, Ebisawa M, El-Gamal YM, et al. International consensus on (ICON) anaphylaxis. World Allergy Organization J. 2014;7(1):9.

9. Dreborg S, Kim H. Authors response. Annals of allergy, Asthma Immunology: official publication of the American College of Allergy, Asthma Immunology. 2018.

10. Andersen HH, Lundgaard AC, Petersen AS, Hauberg LE, Sharma N, Hansen $\mathrm{SD}$, et al. The lancet weight determines wheal diameter in response to skin prick testing with histamine. PLoS ONE. 2016;11(5):e0156211.

11. Kim H, Dinakar C, Mclnnis P, Rudin D, Benain X, Daley W, et al. Inadequacy of current pediatric epinephrine autoinjector needle length for use in infants and toddlers. Annals Allergy Asthma Immunol. 2017;118(6):719-725e1.

12. Duong M, Botchway A, Dela Cruz J, Austin R, McDaniel K, Jaeger C. Skin to intramuscular compartment thigh measurement by ultrasound in pediatric population. West J Emerg Med. 2017;18(3):479-86.

13. Dreborg S, Kim H. Tissue compression and epinephrine deposition. J Allergy Clin Immunol Pract. 2019;7:2096-7.

\section{Publisher's Note}

Springer Nature remains neutral with regard to jurisdictional claims in published maps and institutional affiliations.
Ready to submit your research? Choose BMC and benefit from:

- fast, convenient online submission

- thorough peer review by experienced researchers in your field

- rapid publication on acceptance

- support for research data, including large and complex data types

- gold Open Access which fosters wider collaboration and increased citations

- maximum visibility for your research: over 100M website views per year

At BMC, research is always in progress.

Learn more biomedcentral.com/submissions 